GRASAS Y ACEITES 66 (3)

July-September 2015, e084

ISSN-L: 0017-3495

doi: http://dx.doi.org/10.3989/gya.0838142

\title{
Influence of solid loading on D-xylose production through dilute sulphuric acid hydrolysis of olive stones
}

\author{
M. Cuevas ${ }^{\mathrm{a}}$, M. Saleh ${ }^{\mathrm{a}}$, J.F. García-Martín ${ }^{\mathrm{b}}$ and S. Sánchez ${ }^{\mathrm{a},}$ \\ ${ }^{a}$ Department of Chemical, Environmental and Materials Engineering, University of Jaén,Campus Las Lagunillas, 23071 Jaén, Spain \\ ${ }^{b}$ Instituto de la Grasa, CSIC. Pablo Olavide University Campus- Bldg. 4641013 Seville, Spain \\ ${ }^{\square}$ Corresponding author: ssanchez@ujaen.es
}

Submitted: 27 August 2014; Accepted: 09 February 2015

\begin{abstract}
SUMMARY: The selective hydrolysis of hemicellulose from olive stones was attempted in order to achieve a maximum D-xylose yield. For this aim, batch hydrolysis was conducted under different operating conditions of temperature, acid concentration and solid loading. Firstly, distilled water, sulphuric acid and nitric acid were assessed as hydrolytic agents at different temperatures $\left(200,205,210\right.$ and $\left.220^{\circ} \mathrm{C}\right)$ and at a fixed acid concentration $(0.025 \mathrm{M})$. Sulphuric acid and $200^{\circ} \mathrm{C}$ were selected for the subsequent dilute acid hydrolysis optimization based on the obtained D-xylose yields. The combined influence of solid loading (from 29.3 to $170.7 \mathrm{~g}$ olive stones into $300 \mathrm{~mL}$ acid solution) and sulphuric acid concentration $(0.006-0.034 \mathrm{M})$ on the release of D-xylose was then estimated by response surface methodology. According to a statistical analysis, both parameters had significant interaction effects on D-xylose production. The results illustrated that the higher the solid loading, the higher the required acid concentration. The decrease in the solid/liquid ratio in the reactor had a positive effect on D-xylose extraction and on the amount of acid used. The optimum solid loading and sulphuric acid concentration were determined to be $50 \mathrm{~g}$ (solid/liquid ratio $1 / 6$ ) and $0.016 \mathrm{M}$, respectively. Under these conditions, the predicted D-xylose yield (expressed as $\mathrm{g}$ of sugar per $100 \mathrm{~g}$ of dry matter fed) was 20.4 (87.2\% of maximum attainable).
\end{abstract}

KEYWORDS: D-xylose; Dilute acid hydrolysis; Hemicellulose; Olive stones; Response surface methodology

RESUMEN: Influencia de la carga de sólido en la producción de D-xilosa mediante hidrólisis del hueso de aceituna con ácido sulfúrico diluido. Se ha desarrollado una hidrólisis selectiva de la fracción hemicelulósica del hueso de aceituna con el fin de obtener el máximo rendimiento de D-xilosa. Para ello las hidrólisis se llevaron a cabo en un reactor discontinuo a distintas condiciones de temperatura, concentración de ácido y carga de sólidos. En primer lugar se evaluó la capacidad hidrolítica del agua destilada y de los ácidos nítrico y sulfúrico a distintas temperaturas (200, 205,210 y $\left.220^{\circ} \mathrm{C}\right)$ manteniendo fija la concentración de ácido $(0,025 \mathrm{M})$. A partir de los rendimientos en D-xilosa obtenidos se seleccionó el ácido sulfúrico y una temperatura de $200^{\circ} \mathrm{C}$ para la posterior optimización del proceso. La influencia conjunta de la carga de sólidos (desde 29,3 a 170,7 g de hueso de aceituna en $300 \mathrm{~mL}$ de disolución ácida) y de la concentración de ácido sulfúrico $(0,006-0,034 \mathrm{M})$ sobre los rendimientos de D-xilosa fue determinada mediante metodología de superficie de respuesta. Según el análisis estadístico ambos parámetros tuvieron un efecto interactivo significativo en la producción de D-xilosa. Los resultados mostraron que se requiere mayor concentración de ácido a mayor carga de sólidos. La disminución de la relación sólido/líquido en el reactor tuvo un efecto positivo en la extracción de D-xilosa y en la cantidad de ácido utilizado. Las condiciones óptimas fueron $50 \mathrm{~g}$ de sólidos (relación sólido/ líquido 1/6) y concentración de ácido sulfúrico 0,016 M. Bajo estas condiciones, el rendimiento de D-xilosa predicho, expresado en g de azúcar por cada $100 \mathrm{~g}$ de huesos de aceituna, fue 20,4 (87,2\% del máximo teórico).

PALABRASCLAVES: D-xilosa; Hemicelulosa; Hidrólisis ácida diluida; Hueso de aceituna; Superficie de respuesta

Citation/Cómo citar este artículo: Cuevas M, Saleh M, García-Martín JF, Sánchez S. 2015. Influence of solid loadingon D-xylose production through dilute sulphuric acidhydrolysis of olive stones. Grasas Aceites 66 (3): e084. doi: http://dx.doi.org/10.3989/gya.0838142.

Copyright: (C) 2015 CSIC. This is an open-access article distributed under the terms of the Creative Commons Attribution-Non Commercial (by-nc) Spain 3.0 Licence. 


\section{INTRODUCTION}

Olive stones are a by-product generated in the olive oil extraction and pitted table olive industries. The incorporation of pulp and stone separators in Spanish olive-oil mills has increased the availability of fragmented olive stones (endocarps). In Andalusia alone (Southern Spanish region), the olive-oil industry generates over 450,000 tons per year.

Olive stones are a lignocellulosic biomass and therefore are mainly composed of hemicellulose, cellulose and lignin. Because of their high heating value, roughly $20.0 \mathrm{MJ} \cdot \mathrm{kg}^{-1}$ (Skoulouet al., 2009), the main current application of olive stones is their direct combustion to convert dry biomass into heat or electricity by means of stoves, furnaces, boilers and turbo-generators. However, this biomass has a high content of hemicellulose, ranging between $21.9 \%$ (Fernández-Bolaños et al., 2001) and 28.1\% (Cuevas et al., 2013), which is a potential source of D-xylose. What is more, the removal of hemicellulose (which has lower heating power than cellulose and lignin) from olive stones would increase the heating power of this biomass. The resulting solid after hemicellulose extraction, composed of cellulose and lignin, would also be a valuable raw material for pellet production (García et al., 2012). This solid can also be utilized as a source of D-glucose which, in turn, can be employed for bioethanol or lactic acid production.

Hemicellulose of lignocellulosic biomass can be easily and selectively extracted by dilute acid under mild treatment conditions to obtain D-xylose-rich hemicellulose hydrolysate which is a potential substrate for the manufacture of xylitol (García et al., 2011; Rafiqul and Sakinah, 2013). This compound has a broad range of applications in medical, pharmaceutical, cosmeceutical and food industries. When the target is the recovery of D-xylose instead of D-glucose, dilute acid hydrolysis is still a preferential process over enzymatic hydrolysis due to its lower cost and faster kinetics (García Martín et al., 2013). However, the major drawbacks of acid hydrolysis are potential sugar degradation towards furfural and 5-hydroxymethyl-furfural along with acetic acid generation, which can provoke yeast inhibition in the subsequent fermentation for ethanol or xylitol production (Palmqvist et al., 1999; Montané et al., 2002; García et al., 2012). Sulphuric acid is usually used instead of other acids, such as hydrochloric, nitric and phosphoric acid, because of its low volatility, lower corrosion on equipment and reduced cost (García Martín et al., 2013; Kim et al., 2014). On the other hand, the use of nitric acid leads to the formation of nitrate after hydrolysate neutralization, which could be used as a nitrogen source for the fermentation process (Kim et al., 2014). Nitric acid has never been applied to the hydrolysis of olive stones.
There is a lack of research concerning the dilute acid hydrolysis of olive stones. Few studies deal with D-xylose production; the works are mainly focused on D-glucose and later ethanol production by autohydrolysis, enzymatic hydrolysis, simultaneous saccharification and fermentation, and yeast fermentation (Fernández-Bolaños et al., 2001; Ballesteros et al., 2002; Cuevas et al., 2009). Furfural production has also been assayed with dilute acid hydrolysis as it is an important renewable, non-petroleum based, chemical feedstock (Montané et al., 2002). Only Cuevas et al. (2013) and Saleh et al. (2014) have previously attempted the recovery of D-xylose from olive stones. Cuevas et al. (2013) achieved full D-xylose recovery from hemicellulose by means of enzymatic hydrolysis preceded by autohydrolysis. By contrast, Saleh et al. (2014) aimed for D-xylose recovery in one single step without the need of resorting to the use of enzymes, which enhances the feasibility of the process. By using sulphuric acid as a hydrolytic agent, these authors (Saleh et al., 2014) recovered $89.7 \%$ of the available D-xylose in olive stones.

Nevertheless, these authors (Cuevas et al., 2013; Saleh et al., 2014) assayed a relatively low solid/liquid ratio in the reactor (1/6). The use of higher olive stone loadings has not been assayed. By increasing the solid loading and thus the solid/liquid ratio, the resulting D-xylose concentration after dilute acid hydrolysis will be higher. This can enhance the feasibility of the process (lower capital costs and production cost due to reduced size of equipment and acid amounts).

Once acid hydrolysis is performed and the solid separated, it is necessary to condition the hydrolysate for its subsequent fermentation. The hydrolysate obtained has an extremely low $\mathrm{pH}$. As this $\mathrm{pH}$ is inappropriate for yeast growth, a series of treatments is required for conditioning ( $\mathrm{pH}$ adjustment at a value in the range 3.5 to 4.5 , centrifugation process to eliminate precipitates, and evaporation under vacuum without exceeding $50{ }^{\circ} \mathrm{C}$ in order to avoid the deterioration of the carbohydrates) and sterilization of the sugary liquid.

In the present work, we first assessed the ability of sulphuric acid and nitric acid to hydrolyze olive stone hemicellulose, since the main target is to obtain D-xylose and, as by-product, a solid composed of cellulose and lignin. The acid concentration and temperature assayed were $0.025 \mathrm{M}$ and the range $200-220^{\circ} \mathrm{C}$, respectively, and as control we used distilled water (autohydrolysis). Secondly, the acid that provided the highest D-xylose yields was used for dilute acid hydrolysis optimization. A mathematical model was employed to study the combined influence of acid concentration and olive stone loading into the reactor in the generation of $\mathrm{D}$-xylose. The main target was to assess the impact of solid loading on the performance of the dilute acid hydrolysis and hence on D-xylose production. 


\section{MATERIALS AND METHODS}

\subsection{Raw material}

Olive stones (Olea europaea L. of the variety 'Picual') were provided by a local mill industry from Jaén (Spain). The raw material was dried at room temperature under shade for three weeks and then stored in sealed plastic bags until use.

\subsection{Autohydrolysis and dilute acid hydrolysis}

Experiments were conducted in a $2 \mathrm{~L}$ Parr batch reactor, Series 4522 (Moline, IL, USA). For the preliminary assessment of the hydrolytic power of sulphuric acid and nitric acid, $50 \mathrm{~g}$ of dry olive stones were loaded into the reactor along with $300 \mathrm{~mL}$ (solid/liquid ratio $=1 / 6$ ) of distilled water (autohydrolysis) or the desired acid solution (dilute acid hydrolysis). For the optimization of the dilute sulphuric acid hydrolysis, different olive stone loadings ( $29.3 \mathrm{~g}, 50.0 \mathrm{~g}, 100 \mathrm{~g}, 150.0 \mathrm{~g}$ and $170.7 \mathrm{~g}$ ) were placed into the reactor along with $300 \mathrm{~mL}$ of the pertinent sulphuric acid solution $(0.006 \mathrm{M}, 0.010 \mathrm{M}, 0.020 \mathrm{M}$, $0.030 \mathrm{M}$ or $0.034 \mathrm{M}$ ), i.e. solid /liquid ratios between $1 / 10.23$ and $1 / 1.76\left(\mathrm{~g} \cdot \mathrm{mL}^{-1}\right)$. The mixture was stirred at $250 \mathrm{rpm}$ and heated until the desired maximum temperature was reached $\left(200,205,210\right.$ and $220^{\circ} \mathrm{C}$ for preliminary trials, $200{ }^{\circ} \mathrm{C}$ for dilute acid hydrolysis optimization, respectively). Finally, the reactor was cooled to room temperature in less than $10 \mathrm{~min}$ (residence time at the maximum temperature $=0$ ). After hydrolysis, the content of the reactor was separated by filtration into solid residue and hydrolysate. The former was water-washed to remove any remaining sugars, dried at room temperature and characterized by the methods described in Section 2.4. The liquid fraction was analyzed in D-glucose, D-xylose, L-arabinose, D-galactose, 5-hydroxymethylfurfural (5-HMF) and acetic acid.

The severity parameter of autohydrolyses and acid hydrolyses, $\log \mathrm{R}_{0}$, was calculated according to Overend and Chornet (1987). The parameter $\mathbf{R}_{0}$ combines the effect of reaction time and temperature on the polysaccharide-degradation process as follows:

$$
R_{o}=\int_{o}^{t} e^{t(t)-T r} / 14.75 \mathrm{~d} t
$$

where $T(t)$ is a function that relates the reaction temperature with reaction time $(\mathrm{t})$, and $\operatorname{Tr}$ is the reference temperature $\left(100^{\circ} \mathrm{C}\right)$. More details about the procedure can be found elsewhere since the severity parameter has been widely used in the autohydrolysis of lignocellulose biomasses such as maize, poplar, birch, olive pruning and olive stones (Tortosa et al., 1995; Fernández-Bolaños et al., 2001; Cuevas et al., 2009; García et al., 2010; García Martín et al., 2010).

\subsection{Response surface methodology}

Response surface methodology (RSM) was employed for statistical data treatment and the optimization of sulphuric acid hydrolysis conditions by multiple regression analysis, using the software Model 7.0 software (Umetrics AB, Umeå, Sweden). A $2^{2}$ central composite circumscribed design (CCCD) with two independent variables (sulphuric acid concentration and olive stone loading) at two different levels (from $0.006 \mathrm{M}$ to $0.034 \mathrm{M}$, and from $29.3 \mathrm{~g}$ to $170.7 \mathrm{~g}$, respectively). Four star (axial) points and three central points (Fig. 1) were adopted to find linear, quadratic and interaction effects of independent process variables on experimental responses.

A second-order polynomial model was fitted to the experimental data,

$\mathrm{Y}=\mathrm{b}_{0}+\sum_{\mathrm{i}=1}^{2} \mathrm{~b}_{\mathrm{i}} \cdot \mathrm{X}_{\mathrm{i}}+\sum_{\mathrm{i}=1, \mathrm{j}=1}^{2} \mathrm{~b}_{\mathrm{ij}} \cdot \mathrm{X}_{\mathrm{i}} \cdot \mathrm{X}_{\mathrm{j}}+\sum_{\mathrm{i}=1}^{2} \mathrm{~b}_{\mathrm{ii}} \cdot \mathrm{X}_{\mathrm{i}}^{2}(\mathrm{i}<\mathrm{j})$

where $\mathrm{Y}$ is the response variable, $\mathrm{X}_{\mathrm{i}}$ and $\mathrm{X}_{\mathrm{j}}$ are the experimental factors with coded units, and $\mathrm{b}_{0}, \mathrm{~b}_{\mathrm{i}}$, $b_{i i}$ and $b_{i j}$ are the constant, linear, quadratic and cross product coefficients, respectively. The statistical

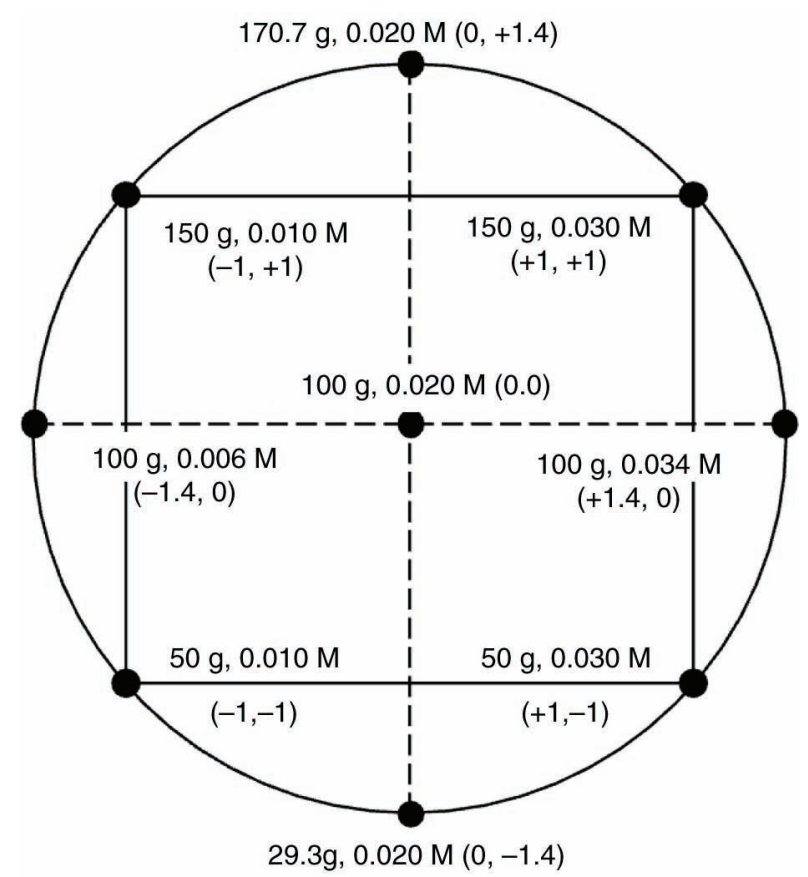

FIGURE 1. Factorial experimental design (square domain) and star points (circular domain). Each black dot represents a dilute sulphuric acid hydrolysis conducted at the variable values indicated (where, ' $\mathrm{g}$ ': $\mathrm{g}$ olive stones and ' $\mathrm{M}$ ': $\mathrm{H}_{2} \mathrm{SO}_{4}$ molarity). The coded values are bracketed (-1 is defined as the lowest value of a variable and +1 is defined as its highest value, whereas the star points are distributed at a distance of 1.4 from the central point. 
validation was performed by one-way ANOVA test with a 95\% confidence, and the optimal condition values were determined based on the response surface methodology.

\subsection{Analytical methods}

The raw material as well as the solids resulting from autohydrolyses and acid hydrolyses were characterized according to moisture (TAPPI T257), insoluble acid lignin (IAL; TAPPI T222 os-74), and ash (TAPPI T211). Neutral detergent fiber (NDF) and acid detergent fiber (ADF) were quantified according to Van Soest and Wine (1967). The percentages of hemicellulose (HEM) and cellulose (CEL) were calculated according to the expressions:

$\mathrm{HEM}=\mathrm{NDF}-\mathrm{ADF}$

$\mathrm{CEL}=\mathrm{ADF}-\mathrm{IAL}$

The percentage of xylans $(20.6 \%)$ and acetyl groups $(4.0 \%)$ in the raw material was determined by a modification of the method proposed by Puls et al. (1985). The potential yield of D-xylose is defined as $0.88 \mathrm{~g}$ xylan per $\mathrm{g}$ pentose. This number results from the quantitative conversion of D-xylose to xylan using the stoichiometric factor 150/132 (ratio of the molecular weight of pentose per molecular weight of anhydro pentoses that makes up xylans). The maximum D-xylose extraction attainable was then $23.4 \%$. Similarly, the conversion factor of acetic acid to the acetyl group is 0.72 and thereby the potential yield of acetic acid was 5.6\%. The concentration of D-glucose, D-xylose, L-arabinose, D-galactose and 5-hydroxymethyl-furfural in the hydrolysates were analyzed by high-performance liquid ionic chromatography (HPLIC) using amperometric detection. The HPLIC (Dionex ICS 3000 , Sunnyvale, CA, USA) was equipped with a CARBOPAD PA20 analytical column $(3 \times 150 \mathrm{~mm})$ in combination with a CARBOPAD PA20 guard column $(3 \times 30 \mathrm{~mm})$. Elution took place at $30{ }^{\circ} \mathrm{C}$. The eluent was $0.002 \mathrm{M} \mathrm{NaOH}$, at a flow rate of $1 \mathrm{~mL} \cdot \mathrm{min}^{-1}$. After dilution, the samples were filtered through a $0.22 \mu \mathrm{m}$ nylon membrane (Millipore). Acetic acid was quantified following the enzymatic method described by Bergmeyer and Möllering (1974). All determinations were performed in duplicate.

\section{RESULTS AND DISCUSSION}

\subsection{Preliminary assessment of the hydrolytic power of sulphuric acid nitric acid}

\subsubsection{Characterization of solid residues}

The percentage of solid recovery (in relation to the raw material) and the composition of the solid wastes, in terms of moisture, hemicellulose, cellulose, acid insoluble lignin, ash and extracts were determined after the hydrolysis processes (Table 1).

The percentage of solid recovery continuously decreased with an increase in the temperature of the process. Therefore, higher solid solubilization was obtained under more severe conditions. The major weight loss in the raw material was attributed to the hydrolysis of the hemicellulose fraction.

When working with distilled water (without acid addition), hemicellulose was completely solubilized solely at $220{ }^{\circ} \mathrm{C}\left(\log \mathrm{R}_{0}=4.1\right)$, which was translated into a noticeable weight loss in raw material $(39.4 \%)$. This result is in agreement with

TABLE 1. Composition of solid residues (in \% w/w) after autohydrolysis and dilute acid hydrolysis

\begin{tabular}{|c|c|c|c|c|c|c|c|c|c|}
\hline $\mathbf{T}\left({ }^{\circ} \mathrm{C}\right)$ & Medium & $\log R_{0}$ & Solid recovery & Moisture & Hemicellulose & Cellulose & Lignin & Ash & Extracts $^{a}$ \\
\hline Original raw material & & & 100.0 & 8.9 & 29.0 & 25.9 & 33.3 & 0.71 & 11.1 \\
\hline 200 & Water & 3.45 & 73.0 & 5.8 & 7.1 & 38.0 & 33.2 & 0.00 & 21.7 \\
\hline 205 & Water & 3.64 & 69.8 & 5.6 & 4.1 & 37.6 & 36.4 & 0.31 & 21.6 \\
\hline 210 & Water & 3.75 & 65.4 & 5.0 & 1.5 & 37.0 & 37.9 & 0.29 & 23.3 \\
\hline 220 & Water & 4.10 & 60.6 & 4.8 & 0.0 & 35.3 & 41.0 & 0.29 & 23.4 \\
\hline 200 & $0.025 \mathrm{M} \mathrm{H}_{2} \mathrm{SO}_{4}$ & 3.46 & 63.5 & 6.2 & 2.2 & 37.1 & 38.1 & 0.00 & 22.6 \\
\hline 205 & $0.025 \mathrm{M} \mathrm{H}_{2} \mathrm{SO}_{4}$ & 3.62 & 60.7 & 4.9 & 0.0 & 37.2 & 40.5 & 0.00 & 22.3 \\
\hline 210 & $0.025 \mathrm{M} \mathrm{H}_{2} \mathrm{SO}_{4}$ & 3.77 & 56.6 & 4.5 & 0.0 & 32.2 & 45.1 & 0.09 & 22.6 \\
\hline 220 & $0.025 \mathrm{M} \mathrm{H}_{2} \mathrm{SO}_{4}$ & 4.04 & 52.8 & 4.7 & 0.0 & 31.5 & 45.0 & 0.15 & 23.4 \\
\hline 200 & $0.025 \mathrm{M} \mathrm{HNO}_{3}$ & 3.53 & 53.1 & 5.0 & 0.0 & 32.7 & 46.7 & 0.00 & 20.6 \\
\hline 205 & $0.025 \mathrm{M} \mathrm{HNO}_{3}$ & 3.61 & 51.9 & 4.8 & 0.0 & 33.0 & 47.1 & 0.03 & 19.9 \\
\hline 210 & $0.025 \mathrm{M} \mathrm{HNO}_{3}$ & 3.76 & 50.1 & 5.0 & 0.0 & 23.6 & 51.1 & 0.29 & 25.0 \\
\hline 220 & $0.025 \mathrm{M} \mathrm{HNO}_{3}$ & 4.01 & 41.0 & 5.3 & 0.0 & 19.9 & 41.9 & 0.28 & 37.9 \\
\hline
\end{tabular}

${ }^{\mathrm{a}}$ Calculated as the difference to $100 \%$. 
that reported by Cuevas et al. (2009), who established that values of $\log \mathrm{R}_{0}$ greater than 4 lead to the total removal of hemicellulose from olive stones by autohydrolysis. By contrast, the use of $0.025 \mathrm{M}$ $\mathrm{H}_{2} \mathrm{SO}_{4}$ or $0.025 \mathrm{M} \mathrm{HNO}_{3}$ completely solubilized the hemicellulosic fraction at all assayed temperatures, along with significant cellulose and lignin removal. This increased the weight loss in raw material up to $47.2 \%$ and $59.0 \%$ using sulphuric acid and nitric acid, respectively.

The cellulose and lignin fractional conversions (defined as $\mathrm{g}$ transformed cellulose or lignin per $\mathrm{g}$ initial cellulose or lignin) were calculated from the compositional data. Cellulose conversion increased with increasing temperature, as was expected. On the contrary, lignin conversion did not follow any trend, probably due to condensation and re-polymerization reactions as well as reactions between lignin and solubilized polysaccharide chains (Tortosa et al., 1995; Heitzet al., 1988; García Martín et al., 2010), which make results difficult to interpret. The percentage of converted lignin remained in the range of 23.7-28.6\%, except for the hydrolysis performed with $0.025 \mathrm{M} \mathrm{HNO}_{3}$ at $220{ }^{\circ} \mathrm{C}$ in which $48.4 \%$ of lignin was solubilized. As a result, the increase in cellulose conversion was not accompanied by an increase in lignin conversion (Fig. 2). This figure also illustrates that cellulose conversion was very low for autohydrolysis and that nitric acid led to higher conversions than sulphuric acid in the assayed conditions.

\subsubsection{Characterization of hydrolysates}

During autohydrolysis, the release of uronic and acetyl groups present in hemicelluloses provides the acidic media that catalyzes the hydrolysis of bonds between hemicellulose and lignin as well as that of carbohydrates (García et al., 2012; Rafiqul and Sakinah, 2013). In our case, the pH of the hydrolysates obtained after autohydrolysis

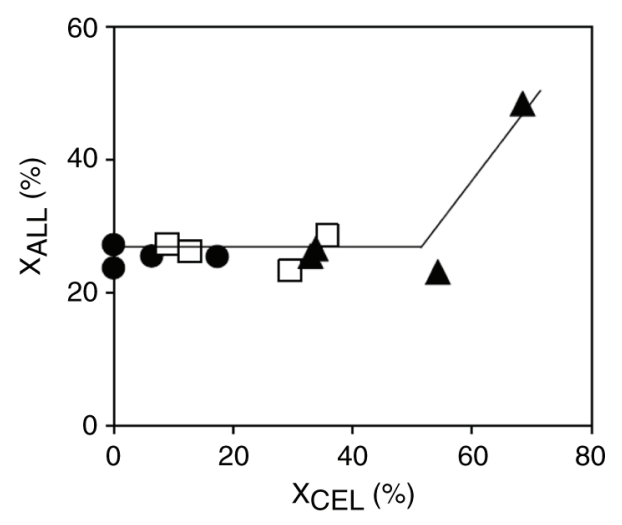

Figure 2. Cellulose $\left(\mathrm{X}_{\mathrm{CEL}}\right)$ and lignin $\left(\mathrm{X}_{\mathrm{AIL}}\right)$ conversion for hydrolysis performed with water $(\bullet), 0.025 \mathrm{M} \mathrm{H}_{2} \mathrm{SO}_{4}(\square)$ and $0.025 \mathrm{HNO}_{3}(\boldsymbol{(})$. ranged between 3.03 and 3.32 . When using $0.025 \mathrm{M}$ $\mathrm{H}_{2} \mathrm{SO}_{4}$ and $\mathrm{HNO}_{3}$ the $\mathrm{pH}$ was fixed at $1.65 \pm 0.03$ due to the acid addition. Autohydrolysis led to low sugar concentrations. Even though hemicellulose was converted to a great extent, sugars remained in oligosaccharide form and thereby D-xylose yields were low (Fig. 3). What is more, yields were negligible, probably due to the low cellulose conversion. By contrast, dilute acid hydrolysis achieved high sugar yields. D-glucose yields concomitantly increased with the aforementioned cellulose conversion with increasing temperatures. However, D-xylose and D-galactose degradation was detected when the temperature increased, as depicted in Fig. 3. This D-galactose degradation, together with the potential (but not detected) D-glucose degradation, was responsible for the increase in the fermentation inhibitor HMF when temperature hydrolysis increased.

Higher D-xylose yields and lower sugars degradation were found when using sulphuric acid instead of nitric acid. The maximum D-xylose yield $\left(18.1 \%, 33.6 \mathrm{~g} \cdot \mathrm{L}^{-1}\right)$ was found at $210{ }^{\circ} \mathrm{C}$ (Figure 3) and $0.025 \mathrm{M} \mathrm{H}_{2} \mathrm{SO}_{4}$. This yield strongly decreased with increasing temperatures. This trend was also observed for D-galactose. Therefore, $210{ }^{\circ} \mathrm{C}$ can be regarded as the temperature threshold for dilute sulphuric acid hydrolysis. Nevertheless, D-xylose and D-galactose yields decreased from $205^{\circ} \mathrm{C}$ when using $0.025 \mathrm{M} \mathrm{HNO}_{3}$. This degradation probably occurred at lower temperatures, but was not detected due to the high, continuous release of sugars into the hydrolysate. The preliminary maximum $\mathrm{D}$-xylose yield achieved by dilute sulphuric acid hydrolysis $(18.1 \%)$ was a promising result, since the potential yield in raw material was $23.4 \%(77.4 \%$ D-xylose extraction). Nevertheless, this result was lower than the maximum D-xylose extraction $(89.7 \%)$ from olive stones by dilute sulphuric acid hydrolysis reported by Saleh et al. (2014). What is more, full D-xylose extraction without degradation has been reported by Cuevas et al. (2013) by optimizing the enzymatic hydrolysis (using a mixture of hemicellulases and $\beta$-glucosidases) of pretreated olive stones by autohydrolysis. Therefore, the following step was the optimization of the dilute acid hydrolysis to enhance D-xylose recovery.

\subsection{Optimization of dilute sulphuric acid hydrolysis. Influence of acid concentration and olive stone loading}

The results obtained during the preliminary assessment of the hydrolytic power of sulphuric acid nitric acid illustrated that the use of dilute sulphuric acid led to the maximum D-xylose yield along with higher solid recoveries. This solid obtained after hydrolysis, composed mainly of cellulose and lignin, is a potential raw material for the manufacture of 

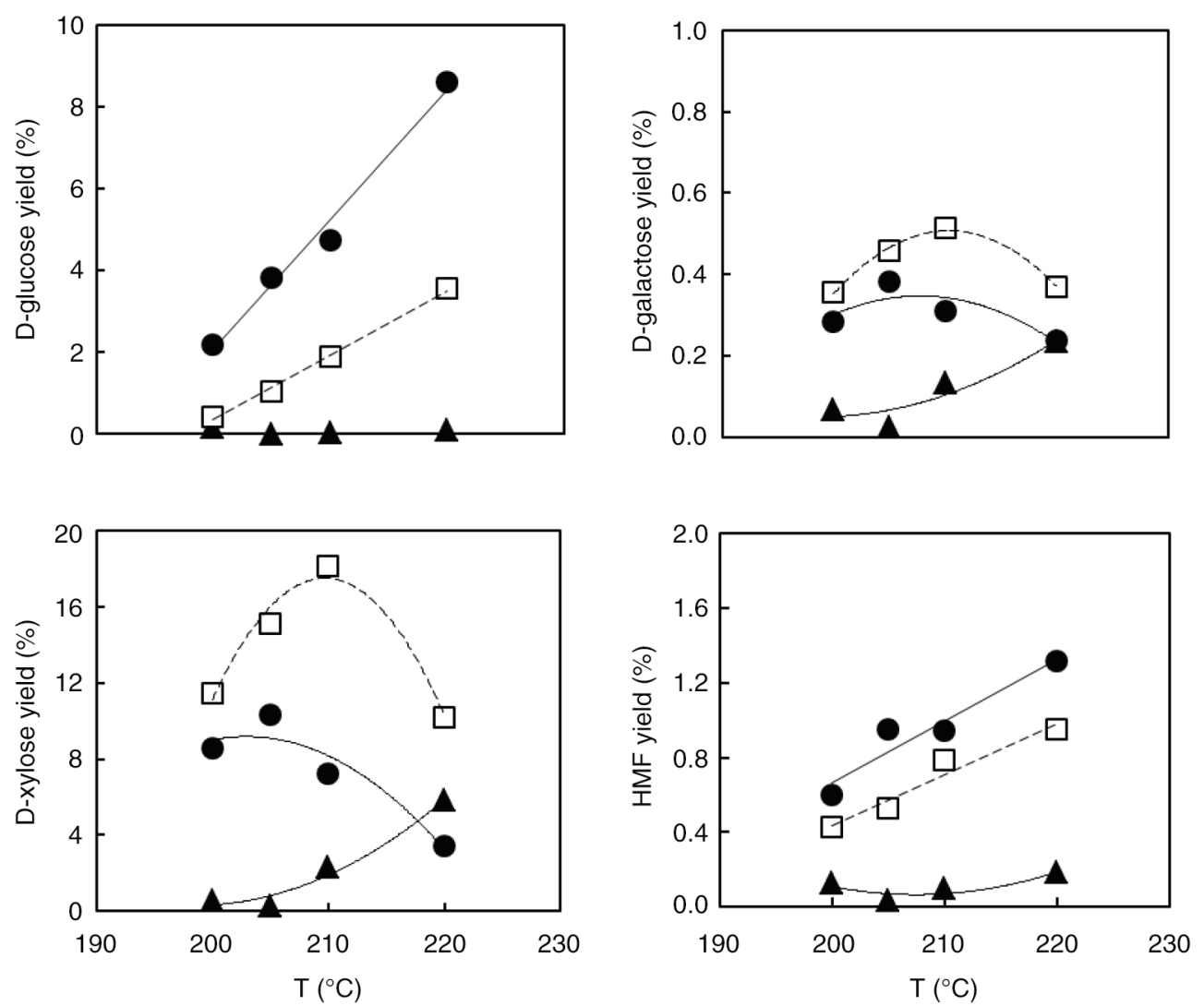

FIGURE 3. Evolution of yields of sugars and 5-hydroxymethyl-furfural (5-HMF) with temperature for hydrolysis performed with water $(\boldsymbol{\Delta}), 0.025 \mathrm{M} \mathrm{H}_{2} \mathrm{SO}_{4}(\square)$ and $0.025 \mathrm{HNO}_{3}(\bullet)$

pellets which are used for heat and power production (García et al., 2012; Rafiqul et al., 2013). Therefore, sulphuric acid was chosen instead of nitric acid for optimizing the dilute acid hydrolysis. In spite of the fact that $210^{\circ} \mathrm{C}$ was the temperature that maximized D-xylose production, $200{ }^{\circ} \mathrm{C}$ was the temperature selected to avoid sugar degradation as far as possible when using $\mathrm{H}_{2} \mathrm{SO}_{4}$ concentrations higher than $0.025 \mathrm{M}$.

\subsubsection{Solid residue: Regression and model analysis}

The conditions assayed for the optimization of dilute sulphuric acid hydrolysis ensured the complete solubilization of hemicellulose (Table 2). Therefore, the whole available D-xylose in olives stones was transferred to hydrolysates. With regard to the percentage of solid recovery, the increase in olive stone loading into the reactor and the decrease in sulphuric acid concentration positively enhanced the solid recovery after hydrolysis (Figure 4). The maximum solid recoveries were roughly $69 \%\left(150 \mathrm{~g}\right.$ and $0.01 \mathrm{M} \mathrm{H}_{2} \mathrm{SO}_{4}, 170.7 \mathrm{~g}$ and $0.02 \mathrm{M} \mathrm{H}_{2} \mathrm{SO}_{4}$ ).

Quadratic polynomials for the percentage of solid recovery (SR, \%) and D-xylose yield ( $\mathrm{Y}_{\mathrm{XYL}}, \%$ ), respectively, were calculated from the experimental design data and validated by ANOVA tests (Table 3 ).

With regard to the percentage of solid recovery (SR, \%), the statistical significance of each parameter $(p$-value $<0.05)$ is shown in Table 3 . The model coefficient of determination $\left(\mathrm{R}^{2}=0.957\right)$ indicated that the model as fitted explained $95.7 \%$ of variability. The adjusted $\mathrm{R}^{2}$ statistic was $93.9 \%$. The good correlation between predicted and actual values is shown in Figure 5.

For the conditions used in this study, the solid recovery model with actual variables as a function of olive stone loading (L, g) and sulphuric acid concentration $(\mathrm{A}, \mathrm{M})$ was:

$$
\text { SR }(\%)=55.2174+0.1956 \mathrm{~L}-279.38 \mathrm{~A}-0.0005 \mathrm{~L}^{2}
$$

\subsubsection{Hydrolysate composition: Regression and model analysis}

D-xylose was found to be the main sugar in hydrolysates, as expected. D-xylose yield was much higher than those of other hemicellulosic sugars (L-arabinose, D-galactose and D-glucose) and was strongly dependent on experimental operating conditions (Table 4). 
Influence of solid loading on D-xylose production through dilute sulphuric acid hydrolysis of olive stones $\bullet$

TABLE 2. Solid recovery and composition of solids after dilute sulphuric acid hydrolysis as a function of olive stone loading into the reactor and sulphuric acid concentration

\begin{tabular}{lccllll}
\hline Run number & Loading $(\mathbf{g})$ & $\mathbf{H}_{\mathbf{2}} \mathbf{S O}_{\mathbf{4}}(\mathbf{M})$ & $\mathbf{S R}(\%)$ & HEM (\%) & CEL (\%) & AIL (\%) \\
\hline 1 & 29.3 & 0.020 & 54.1 & 0.0 & 40.8 & 45.1 \\
2 & 50.0 & 0.010 & 62.8 & 0.0 & 34.1 & 42.3 \\
3 & 50.0 & 0.030 & 54.7 & 0.6 & 34.9 & 43.8 \\
4 & 100.0 & 0.006 & 67.5 & 0.0 & 35.3 & 40.7 \\
$5,6,7$ & 100.0 & 0.020 & $64.4 \pm 1.3$ & $0.0 \pm 0.0$ & $35.6 \pm 2.4$ & $40.3 \pm 0.8$ \\
8 & 100.0 & 0.034 & 60.2 & 0.0 & 33.0 & 45.6 \\
9 & 150.0 & 0.010 & 69.0 & 0.0 & 20.1 & 55.5 \\
10 & 150.0 & 0.030 & 65.1 & 0.0 & 34.3 & 40.5 \\
11 & 170.7 & 0.020 & 69.2 & 0.0 & 33.1 & 40.1 \\
\hline
\end{tabular}

SR: solid recovery, HEM: hemicellulose, CEL: cellulose, AIL: acid insoluble lignin.

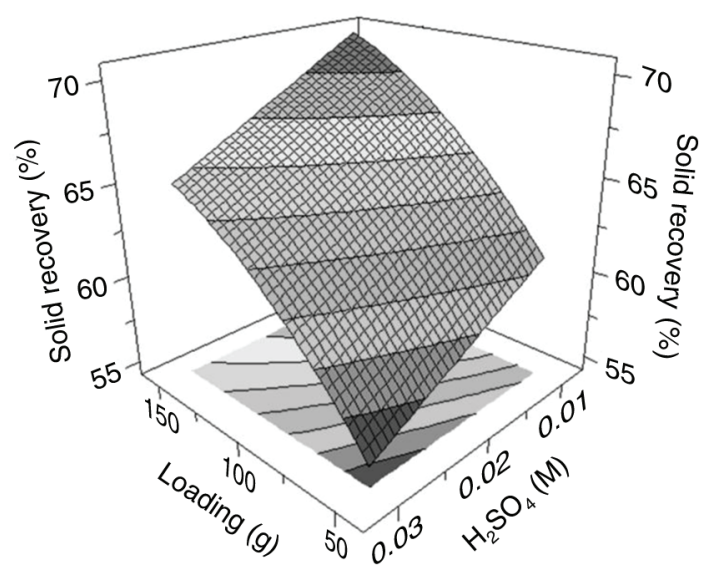

FIGURE 4. Response surface plot of the effect of olive stone loading and sulphuric acid concentration on the percentage of solid recovery.

The resulting equation for the percentage of D-xylose yield $\left(\mathrm{Y}_{\mathrm{XYL}}, \%\right)$ based on actual values was as follow:

$$
\begin{aligned}
\mathrm{Y}_{\mathrm{XYL}}(\%) & =20.5959-0.0908 \mathrm{~L}+316.6140 \mathrm{~A} \\
& -0.0008 \mathrm{~L}^{2}-25276.6 \mathrm{~A}^{2}+9.775 \mathrm{~L} \mathrm{~A}
\end{aligned}
$$

where $\mathrm{L}$ and $\mathrm{A}$ stand for the actual olive stone loadings and acid concentrations, respectively.

The D-xylose yield model obtained was statistically significant ( $\mathrm{p}$-value $<0.001$ ). The goodness of fit $\left(\mathrm{R}^{2}\right)$ was 0.995 and thereby the model as fitted explained $99.5 \%$ of variability for D-xylose yield while the remaining $0.5 \%$ was explained by the residue (Table 3). According to RMS outputs, $20.4 \mathrm{~g}$ $\mathrm{D}$-xylose can be obtained from $100 \mathrm{~g}$ olive stones $(87.2 \% \mathrm{D}$-xylose extraction) under the most favorable conditions ( $50 \mathrm{~g}$ solid loading, $0.016 \mathrm{M} \mathrm{H}_{2} \mathrm{SO}_{4}$ ). This yield is comparable to those achieved by Saleh et al. (2014) and Cuevas et al. (2013). Saleh et al.
(2014) extracted $89.7 \%$ of the potential D-xylose of olive stones (20.9 g D-xylose per $100 \mathrm{~g}$ olive stones) by dilute sulphuric acid hydrolysis with the same solid/liquid ratio (1/6) at a temperature of $195^{\circ} \mathrm{C}$, a reaction time of $5 \mathrm{~min}$ at this temperature, and a sulphuric acid concentration of $0.025 \mathrm{M}$. In the meantime, Cuevas et al. (2013) achieved full D-xylose recovery (23.3 g D-xylose per $100 \mathrm{~g}$ olive stones) by the synergistic action of hemicellulases and $\beta$-glucosidases on pre-treated olive stones by autohydrolysis. Perceptibly, dilute sulphuric hydrolysis can achieve the same yields than enzymatic hydrolysis (preceded by a pre-treatement) in one single stage.

Results illustrated that the higher the solid loading, the higher the required acid concentration to achieve the maximum D-xylose yield. From the response surface and mixture contour (Figure 6) plots it was concluded that the highest D- xylose production was achieved nearby the diagonal that pass through the points $(-1,-1),(0,0)$ and $(+1,+1)$ of the factorial design (Figure 1), i.e. $50 \mathrm{~g}$ and $0.01 \mathrm{M}, 100 \mathrm{~g}$ and $0.02 \mathrm{M}$, and $150 \mathrm{~g}$ and $0.03 \mathrm{M}$, respectively. The low sulphuric acid concentration was a hindrance to achieving high D-xylose yields for the conditions above this diagonal of the factorial design (high solid loadings). On the contrary, the excess of acid in the conditions below the diagonal of the factorial design (low solid loadings) probably led to sugar degradation to some extent which resulted in slightly lower D-xylose yields. Similarly, the maximum yields of the other hemicellulosic sugars (L-arabinose and D-galactose) were found at the diagonal points of the factorial design (Table 4). Unfortunately, the conditions which maximized solid recovery (Table 2) did not correspond to those that minimized hemicellulosic sugar yield (Table 4). Furthermore, solid solubilization was related to D-glucose production as maximum D-glucose yields were found at the conditions that minimized solid recovery, namely run numbers 1 and 3 (Tables 2 and 4). This fact is logical since 
TABLE 3. Estimated effects (EE), standard errors (SE) and significance level (p) for the models of solid recovery percentage $(\mathrm{SR})$ and $\mathrm{D}$-xylose yield $\left(\mathrm{Y}_{\mathrm{XYL}}\right)$ responses

\begin{tabular}{|c|c|c|c|c|c|}
\hline Response variable & Sourc & & EE & SE & p-value $($ Prob $>$ F) \\
\hline \multirow[t]{6}{*}{$\mathrm{RS}, \%$} & Constant & & 64.1524 & \pm 0.5329 & 0.0000 \\
\hline & $\mathrm{X}_{\mathrm{L}}$ & & 4.7442 & \pm 0.4486 & 0.0000 \\
\hline & $\mathrm{X}_{\mathrm{A}}$ & & -2.7938 & \pm 0.4486 & 0.0004 \\
\hline & $\mathrm{X}_{\mathrm{L}} \cdot \mathrm{X}_{\mathrm{L}}$ & & -1.2586 & \pm 0.5104 & 0.0431 \\
\hline & $\mathrm{R}^{2}$ & 0.957 & & & \\
\hline & $\mathrm{R}_{\text {adjust }}^{2}$ & 0.939 & & & \\
\hline \multirow[t]{8}{*}{$\mathrm{Y}_{\mathrm{XYL}}, \%$} & Constant & & 19.0733 & \pm 0.2919 & 0.0000 \\
\hline & $\mathrm{X}_{\mathrm{L}}$ & & -2.9772 & \pm 0.1787 & 0.0000 \\
\hline & $\mathrm{X}_{\mathrm{A}}$ & & 2.8305 & \pm 0.1787 & 0.0000 \\
\hline & $\mathrm{X}_{\mathrm{L}} \cdot \mathrm{X}_{\mathrm{L}}$ & & -2.0525 & \pm 0.2128 & 0.0002 \\
\hline & $\mathrm{X}_{\mathrm{A}} \cdot \mathrm{X}_{\mathrm{A}}$ & & -2.5277 & \pm 0.2128 & 0.0000 \\
\hline & $\mathrm{X}_{\mathrm{L}} \cdot \mathrm{X}_{\mathrm{A}}$ & & 4.8875 & \pm 0.2528 & 0.0000 \\
\hline & $\mathrm{R}^{2}$ & 0.995 & & & \\
\hline & $\mathrm{R}_{\text {adjust }}{ }^{2}$ & 0.991 & & & \\
\hline
\end{tabular}

$\mathrm{X}_{\mathrm{L}}$ : olive stone loading (in coded form), $\mathrm{X}_{\mathrm{A}}$ : sulphuric acid (in coded form). Significance level was defined as $\mathrm{p}<0.05$.

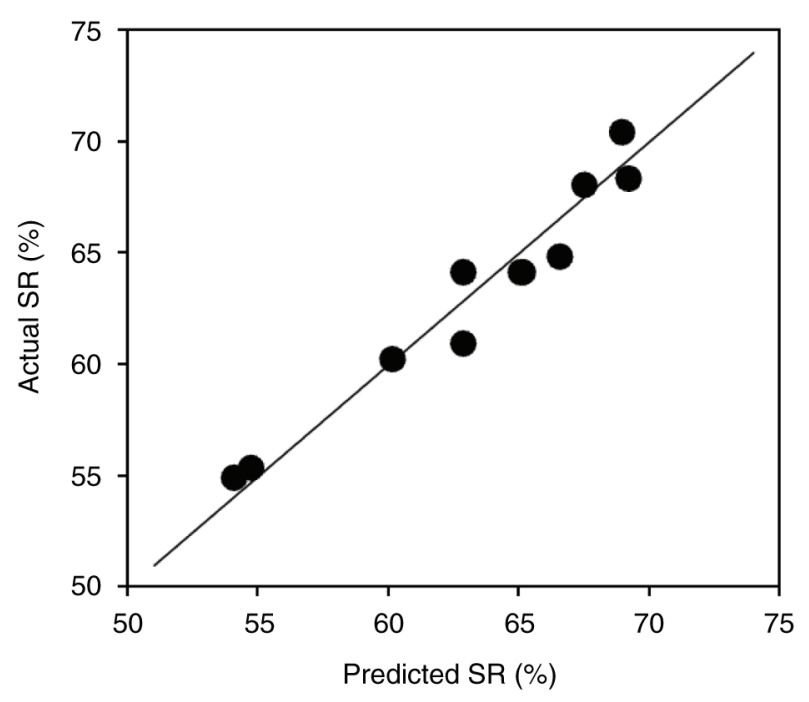

FIGURE 5. Scatter plot diagram of actual values against predicted values for the solid recovery model.

the increase in cellulose hydrolysis, and therefore the increase in D-glucose yield, leads to lower solid recovery after dilute sulphuric acid hydrolysis.

Finally, no trend was found either for acetic acid or 5-hydroxymethyl-furfural. Complete release of acetic acid arising from acetyl groups, even exceeding the theoretical maximum attainable $(5.6 \%)$, was found (Table 4). High concentrations of acetic acid can inhibit the microbial conversion of D-xylose to xylitol. Nevertheless, some xylose-fermenting yeasts, mainly from the Candida genus, have been found not to be inhibited by acetic acid. In this way,
García et al. (2011) found a slow consumption of acetic acid by Candida tropicalis from the start of the fermentation process until depletion. These authors (García et al., 2011) emphasized that the acetic acid consumption was simultaneous with those of D-glucose and D-xylose. With regard to 5-hydroxymethyl-furfural yields, the values achieved were low and cannot be regarded as a potential source of inhibition in the subsequent fermentation of sugars.

On a large scale, xylitol is currently produced by the chemical reduction in D-xylose derived mainly from wood hydrolysates (Parajó et al., 1998; Winkelhausen and Kuzmanova, 1998). The xylitol production from olive stones, by acid hydrolysis and subsequent fermentation (using non-traditional yeasts) could be an interesting alternative to the current synthesis.

\section{CONCLUSIONS}

Among the different assayed hydrolytic agents, sulphuric acid was selected over nitric acid and distilled water because dilute sulphuric acid hydrolysis led to the maximum D-xylose yield along with higher solid recoveries. The main drawbacks of using water and nitric acid were the low D-xylose concentrations achieved and the sugar degradation, respectively. The dilute acid hydrolysis of olive stones performed in batch mode at different sulphuric acid concentrations and solid loadings fit the proposed secondorder polynomial equation. D-xylose was found to be the main sugar in hydrolysates. Both variables were closely related because the higher the solid loading, the higher the required acid concentration 
Influence of solid loading on D-xylose production through dilute sulphuric acid hydrolysis of olive stones $\bullet 9$

TABle 4. Product yields (as $\mathrm{g} \cdot 100 \mathrm{~g}^{-1}$ raw material) in hydrolysates obtained in the optimization of dilute sulphuric acid hydrolysis

\begin{tabular}{lccccccccc}
\hline Run number & $\mathbf{1}$ & $\mathbf{2}$ & $\mathbf{3}$ & $\mathbf{4}$ & $\mathbf{5 , 6 , 7}$ & $\mathbf{8}$ & $\mathbf{9}$ & $\mathbf{1 0}$ & $\mathbf{1 1}$ \\
\hline Loading $(\mathrm{g})$ & 29.3 & 50.0 & 50.0 & 100.0 & 100.0 & 100.0 & 150.0 & 150.0 & 170.7 \\
$\mathrm{H}_{2} \mathrm{SO}_{4}(\mathrm{M})$ & 0.020 & 0.010 & 0.030 & 0.006 & 0.020 & 0.034 & 0.010 & 0.030 & 0.020 \\
$\mathrm{XYL}$ & 18.8 & 20.0 & 15.6 & 9.6 & $19.1 \pm 0.5$ & 18.1 & 4.0 & 19.1 & 10.8 \\
$\mathrm{ARA}$ & 0.52 & 0.95 & 0.67 & 0.97 & $1.10 \pm 0.02$ & 0.88 & 0.87 & 1.10 & 0.81 \\
$\mathrm{GAL}$ & 0.53 & 0.54 & 0.54 & 0.40 & $0.55 \pm 0,01$ & 0.49 & 0.36 & 0.54 & 0.39 \\
$\mathrm{GLU}$ & 1.10 & 0.62 & 2.50 & 0.00 & $0.00 \pm 0.00$ & 0.94 & 0.00 & 0.14 & 0.00 \\
$\mathrm{ACE}$ & 3.2 & 3.3 & 2.5 & 4.7 & $6.3 \pm 1.2$ & n.a. & 4.6 & 6.4 & 3.2 \\
$\mathrm{HMF}$ & 0.01 & 0.00 & 0.27 & 0.00 & $0.03 \pm 0.02$ & 0.01 & 0.00 & 0.12 & 0.11 \\
\hline
\end{tabular}

XYL: D-xylose, ARA: L-arabinose, GAL: D-galactose, GLU: D-glucose, ACE: acetic acid, HMF: 5-hydroxymethyl-furfural.

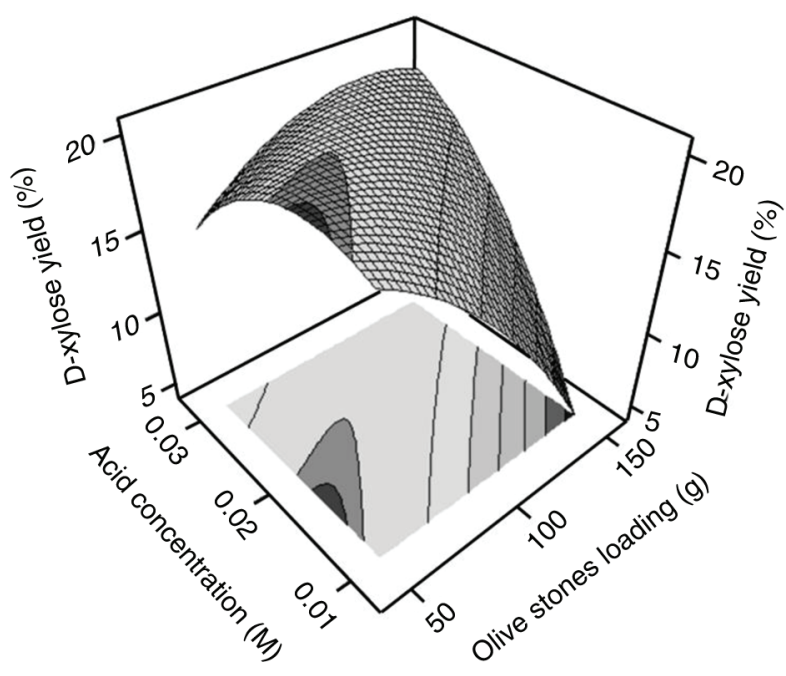

FIGURE 6. Response surface plot of the effect of olive stone loading and sulphuric acid concentration on D-xylose yield.

to achieve the maximum D-xylose yield. Therefore, the use of high solid loadings could be a hindrance for D-xylose recovery by dilute acid hydrolysis because of the high acid concentrations required. The effective level for D-xylose production was $50 \mathrm{~g}$ olive stone loading (solid/liquid ratio $=1 / 6, \mathrm{~g} \cdot \mathrm{mL}^{-1}$ ) and $0.016 \mathrm{M}$ sulphuric acid solution. Under these conditions, $20.4 \mathrm{~g}$ of D-xylose $(87.2 \%$ of the potential D-xylose) was predicted to be obtained. It is worth noting that high D-xylose extraction was achieved in one single step under controlled treatment conditions. Therefore, the D-xylose-rich hydrolysate obtained from this largely available, renewable agricultural residue by dilute acid hydrolysis could be fermented to xylitol, a value-added product. Furthermore, the residue obtained after hydrolysis was composed primarily of cellulose and lignin, which makes it an excellent raw material for the manufacture of pellets.

\section{ACKNOWLEDGMENTS}

This work was funded by the Projects 01272/2005 and AGR/6509 (Andalusia Regional Government, Spain). The authors would like to acknowledge 'S.C.A. San Juan' (Jaén, Spain) for the supply of olive stones. Marwa Saleh also acknowledges a grant from the AECI (Spain).

\section{REFERENCES}

Ballesteros I, Oliva JM, Negro MJ, Manzanares P, Ballesteros M. 2002. Proceso de sacarificación celulósica del residuo de la extracción del aceite de oliva en etanol. Grasas Aceites 53, 282-288.

Bergmeyer H, Möllering H. 1974. Acetic acid, in Bergmeyer $\mathrm{H}$ (Ed.) Methods of enzymatic analysis. Academic Press, New York, $1520-1528$.

Cuevas M, Sánchez S, Bravo V, Cruz N, García JF. 2009. Fermentation of enzymatic hydrolysates from olive stones by Pachysolen tannophilus. J. Chem. Technol. Biotechnol. 84, 461-467. http://dx.doi.org/10.1002/jctb. 2064.

Cuevas M, García JF, Cruz N, Sánchez S. 2013. Generation of D-xylose by hydrothermal treatment of olives endocarps and enzymatic hydrolysis of oligosaccharides. Afinidad 562, 99-106.

Fernández-Bolaños J, Felizón B, Heredia A, Rodríguez R, Guillén R, Jiménez A. 2001. Steam-explosion of olive stones: hemicellulose solubilization and enhancement of enzymatic hydrolysis of cellulose. Bioresource Technol. 79, 53-61. http://dx.doi.org/10.1016/S0960-8524(01)00015-3.

García JF, Sánchez S. Bravo V, Cuevas M. 2010. Autohydrolysis and acid post hydrolysis of olive pruning debris. Afinidad 548, 279-282.

García Martín JF, Cuevas M, Bravo V, Sánchez S. 2010. Ethanol production from olive pruning by autohydrolysis and fermentation with Candida tropicalis. Renew. Energ. 35, 1602-1608. http://dx.doi.org/10.1016/j.renene.2009.12.015.

García JF, Sánchez S, Bravo V, Cuevas M, Rigal L, Gaset A. 2011. Xylitol production from olive-pruning debris by sulphuric acid hydrolysis and fermentation with Candida tropicalis. Holzforschung 65, 59-65.

García JF, Sánchez S, García J. 2012. Ethanol from Biomass: Application to the Olive-Pruning Debris, in Carasillo DA (Ed.) Liquid Fuels: Types, Properties and Production. Nova Science Publishers, New York, 239-254.

García Martín JF, Sánchez S, Cuevas M. 2013. Evaluation of the effect of the dilute acid hydrolysis on sugars release from olive prunings. Renew. Energ. 51, 382-387. http:// dx.doi.org/10.1016/j.renene.2012.10.002. 
Heitz M, Rubio M, Doat J, Overend RP, Chornet E. 1988. Liquefaction par fractionnement de deux bois tropicaux: Conversion et solubilization aprés un traitement thérmomechanique. Cah Sci Cent Tech For Trop Nogent-surMarne 9, 67-102.

Kim I, Lee B, Park J-Y, Choi S-A, Han J-I. 2014. Effect of nitric acid on pretreatment and fermentation for enhancing ethanol production of rice straw. Carbohyd. Polym.99, 563- 567. http://dx doi.org/10.1016/j.carbpol.2013.08.092.

Montané D, Salvadó J, Torras C, Farriol X. 2002. Hightemperature dilute acid hydrolysis of olives stones for furfural production. Biomass Bioener. 22, 295-304. http://dx.doi. org/10.1016/S0961-9534(02)00007-7.

Overend RP, Chornet E. 1987. Fractionation of lignocellulosics by steam-aqueous pretreatment. Phil. Trans. Roy. Soc. London A. 321, 523-536. http://dx.doi.org/10.1098/rsta.1987.0029.

Palmqvist E, Grage H, Meinander NQ, Hahn-Hägerdal B. 1999. Main and interaction effects of acetic acid, furfural and p-hidroxibenzoic acid on growth and ethanol productivity of yeasts. Biotechnol. Bioeng. 63, 46-55. http://dx.doi. org/10.1002/(SICI)1097-0290(19990405)63:1<46::AIDBIT5 $>3.0 . \mathrm{CO} ; 2-\mathrm{J}$.

Parajó JC, Domínguez H, Domínguez JM. 1998. Biotechnological production of xilitol. Part 1: Interest of xylitol and fundamentals of its biosynthesis. Bioresource Technol. 65, 191-201. http://dx.doi.org/10.1016/S0960-8524(98)00038-8.
Puls J, Poutanen K, Körner H, Viikari L. 1985. Biotechnical utilization of wood carbohydrates after steaming pretreatment. Appl. Microb. Biotechnol. 22, 416-423. http://dx.doi. org/10.1007/BF00252783.

Tortosa JF, Rubio M, Demetrio G. 1995. Autohidrólisis de tallo de maíz en suspensión acuosa. Afinidad 52, 181-188.

Rafiqul ISM, Sakinah AMM. 2013. Processes for the Production of Xylitol-A Review. Food Rev. Int. 29,127-156. http:// dx.doi.org/10.1080/87559129.2012.714434.

Saleh M, Cuevas M, García JF, Sánchez S. 2014. Valorization of olive stones for xylitol and ethanol production from dilute acid pretreatment via enzymatic hydrolysis and fermentation by Pachysolen tannophilus. Biochem. Eng. J. 90, 286-293. http://dx.doi.org/10.1016/j.bej.2014.06.023.

Skoulou V, Swiderski A, Yang W, Zabaniotou A. 2009. Process characteristics and products of olive kernel high temperature steam gasification (HTSG). Bioresource Technol. 100, 2444-2451. http://dx.doi.org/10.1016/j.biortech.2008. 11.021 .

Van Soest PJ, Wine RH. 1967. Use of detergents in the analysis of fibrous feed. IV. The determination of plant cell wall constituents. J. Assoc. Off. Anal. Chem. 50, 50-5.

Winkelhausen E, Kuzmanova S. 1998. Microbial conversion of D-xylosa to xylitol. J. Ferment. Bioeng. 86, 1-14. http:// dx.doi.org/10.1016/S0922-338X(98)80026-3. 